\title{
Ficções dramatúrgicas e cenográficas
}

\author{
Maria Helena Serôdio e Paulo Eduardo Carvalho
}

De 5 a 7 de Julho passado, no âmbito do 24. ${ }^{\circ}$ Festival de Teatro de Almada e com o apoio e proverbial entusiasmo do seu director Joaquim Benite (e da equipa excepcional de colaboradores de que tem sabido rodear-se), a Associação Portuguesa de Críticos de Teatro organizou um seminário internacional de críticos propondo como tema central do debate "Ficções dramatúrgicas e cenográficas: convergências / confrontações". A iniciativa inscreveu-se no conjunto de encontros organizados sob a égide da Associação Internacional de Críticos de Teatro, com a designação de "Cultural Bridges" ("Pontes culturais"), razão pela qual contámos com a colaboração de diversos colegas ligados à actividade da nossa congénere internacional.

Independentemente das questões várias e das perspectivas diversas para que apontavam os argumentos contidos no temário, uma das razões que elegemos como linha interpelativa envolvia o novo Teatro Municipal de Almada (o belo edificio azul), concebido pelos arquitectos Manuel Graça Dias e Egas José Vieira, projecto este que, de resto, nos parecia fundamental dar a conhecer aos nossos convidados estrangeiros. E tivemos o privilégio de poder contar com a participação de Manuel Graça Dias que não apenas apresentou, de forma competente e apaixonada, o projecto, definindo os parâmetros da construção - em termos técnicos, estéticos, teatrais e de implantação urbana -, como antecipou também, de forma brilhante, algumas das questões implicadas no debate proposto. Foi assim possivel, ao mesmo tempo, apresentar um dos nossos mais interessantes projectos de arquitectura teatral dos últimos anos, e ancorar a nossa reflexão num entendimento da arte de cena que já não poderá hoje ser sumariamente reduzido à dicotomia texto versus cena ou palavras versus efeitos visuais.

Outra razão de materialidade cénica rodeava a iniciativa, com o anúncio em meados de Junho de que o cenógrafo português João Mendes Ribeiro recebera a medalha de ouro da Quadrienal de Praga com o seu projecto expositivo "Arquitecturas em palco" que, de algum modo, implicava dois vectores fundamentais: "a cenografia como representação arquitectónica" e "a exploração do espaço e do objecto enquanto extensão do corpo humano".
Inevitavelmente estes eram dois dos parâmetros ordenadores da discussão que nos propúnhamos fazer e Ian Herbert, que participara no certame da República Checa, soube mobilizar alguns dos argumentos para que remetiam estas propostas.

No espaço privilegiado da Casa da Cerca, em Almada (onde era possivel na altura apreciar uma retrospectiva da obra gráfica de Costa Pinheiro), e com uma moldura humana de raro valor e motivação, o debate estendeu-se por três dias e pôde contar não apenas com a conferência de Aleks Sierz e as comunicações formais de críticos e académicos convidados que aqui se transcrevem, mas também com um debate vivo e animado envolvendo artistas, críticos e estudiosos portugueses, como Joaquim Benite, Jorge Silva Melo, João Luiz, José Martins, Maria João Brilhante, Ana Isabel Vasconcelos, João Carneiro, Rui Pina Coelho, Sebastiana Fadda, Rita Martins, Marta Costa Dias, entre outros, e colegas estrangeiros que connosco especularam em torno de questões candentes do teatro nosso contemporâneo. Entre colegas estrangeiros que participavam no Festival pudemos ver Mário Rojas, Mariana da Silva, Manuel Sesma, Osvaldo Obregón e Antón Lamapereira, entre outros, destacando-se também pela vivacidade das interpelações a poetisa canadiana Patrícia Keeney, o que veio em muito animar o debate.

Com curiosas deambulações em torno do imaginário que o teatro constrói, não faltaram argumentos que sinalizavam o poder encantatório dos lugares criados ou sugeridos em cena para desencadearem ficções capazes de prescindir da palavra dita, mas que mobilizam ideias, sentidos e valores de peso e consistência imaginativa. Concitavam-se exemplos de estridência visual (acompanhada de sedutores ambientes sonoros), de que falou Hervé Guay, ou formas de expansão espacial em espectáculos site-specific; invocavam-se razões poéticas - ou "ditirâmbicas", na expressão de Don Rubin - que pareciam melhor corresponder às exigências do "reduto visionário da maquinação mais puramente teatral das coisas imaginadas - o escritor".

Mas no cruzamento de caminhos que envolvem as complexas e variadas formulações teatrais, algumas 


\footnotetext{
Teatro Municipal de Almada (Teatro Azul), projecto de Manuel Graça Dias e Egas José Vieira, com Gonçalo Afonso Dias.
}

Imagem do Sala Principa

do Teatro Municipal de Almada, com cortina de Pedro Calapez.

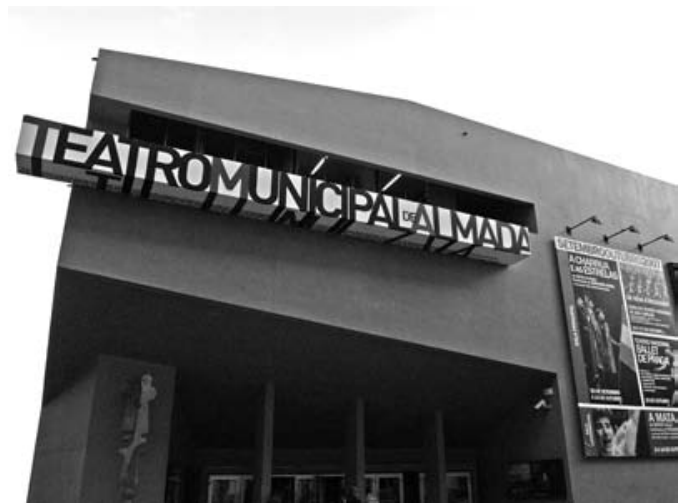

evidências apontavam no sentido de que fala Béatrice Picon-Vallin, de que o teatro é, de facto, uma "arte figurativa" (2004: 12), pelo que mesmo as palavras quando são ditas em cena, se transformam, inscrevendo-se num espaço que "as desestabiliza, concretiza, densifica, modifica, e torna visiveis" (Ibidem). E Maria João Brilhante apontava justamente para o facto indiscutivel de que em teatro as palavras são ditas num espaço concreto, provêm de um corpo vivo e são acompanhadas por uma especificidade da voz e por todo um comportamento físico que necessariamente as radica à imagem de cena. Afinal é a acção e não a palavra o termo de ancoragem da própria posição aristotélica.

Recordando as etapas históricas que marcaram a transformação do uso e valor do espaço no teatro, Juan António Hormigón falou da sua geometrização no início do século $X X$, da tendência importante no sentido do seu esvaziamento e austeridade, mas também das consequências produtivas da introdução da luz eléctrica e posteriores tecnologias mais sofisticadas, bem como do retorno mais recente a formas de espacialidade do teatro medieval e barroco (na deambulação site-specific, nomeadamente), sublinhando três importantes momentos de reconfiguração do imaginário cénico trazidas por Meyerhold ( 0 inspector de Gogol), Berliner Ensemble (Coriolano, de Shakespeare) e Strehler (Zaragata em Chioggia, de Goldoni).

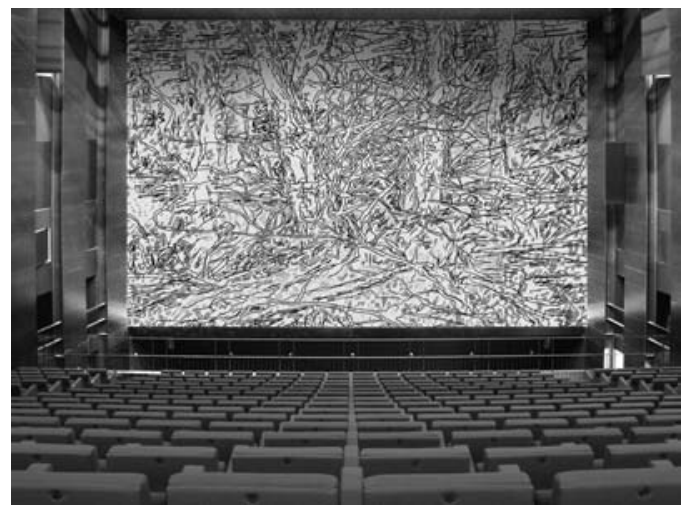

Na discussão destes tópicos, era inevitável questionar também a marca contemporânea que poderíamos eventualmente localizar na prática teatral dos nossos dias, pelo que se avaliava a natural contaminação de temas e formulações vindas da história, da sociologia, ou da vida política, no sentido de identificar núcleos problematizadores das ficções dramatúrgicas e cénicas. E nas matérias de cena, difícil é não perceber o esplendor das fórmulas híbridas que o teatro tem usado para complexificar o imaginário, fortalecer o fascínio, dividir os gostos, fazer explodir as certezas.

Assim, também nas narrativas informadas e problematizadoras de Steve Capra, Yun-Cheol Kim ou Jean-Pierre Han, ouvimos ainda falar do teatro em Nova Iorque, Coreia e França. E foram muitos os exemplos referidos, evocando percursos argumentativos, ligações emotivas e experiências vivenciais que mantêm o teatro como lugar de encontro, ainda que nesse encontro se localizem os axiomáticos factores de conflito que estão, afinal, no centro da vida e do real e nele cartografam o fio de Ariadne da história.

\section{Referência bibliográfica}

PICON-VALLIN, Béatrice (org.) (2004), La scène et les images, Paris, CNRS, Les voies de la création théâtrale, $n .{ }^{\circ} 21$. 